\title{
Why we wash our hands
}

$\mathrm{F}$ ive am Sunday in Toronto, Françoise Pilon was almost fully dilated in the case-room when she screamed, "Je vais mourir!" Her French-speaking nurse, from northern Ontario, checked the patient's vitals, the monitor, and reviewed her history.

The woman had lost three pregnancies.

"My baby will die." Françoise wrung her hands.

"Nonsense," the case nurse said, "everything's perfect."

And everything did work out as the case nurse suggested. At seven the woman delivered a healthy boy with no difficulty. Still, the patient seemed more uneasy. The case nurse decided to remain past her shift. She phoned home that she would be late.

"You see? He's fine," the nurse said. "Feeling better?"

"Something will happen." Françoise crossed herself. "How is my boy?" she moaned. She washed her hands. She had been washing her hands with antiseptic soap and warm water, drying her hands and then washing them again.

She checked her infant's fingers, toes and head.

The woman's friend, Richard, a towering dark man, stroked her hair. "Ça va, Françoise." He turned to the nurse. "She's spooked." Richard's eyes were damp. "Why does she check and wash her hands?"

"Françoise is fearful. Are you her partner?"
"Three years - longer than anyone," Richard said. "He is my son, thank God."

A half-hour later the infant was taken to the nursery. Françoise fell asleep.

"Why did the others die?" the nurse whispered.

"If you got beat-up, kicked, day after day, you'd be dead," Richard said.

"What do you mean?" the nurse asked.

"Françoise was trapped in the house. She didn't leave until later. She has nightmares. I think it was her father - you know." Richard said.

The nurse glanced at Françoise, still asleep.

"No," she said. "Tell me."

"It's a feeling I got. Françoise won't talk. He made her babies and then made her lose them - you know," Richard's brow tensed. "She feels too lousy to speak."

"Are you sure?"

Richard bent forward and whispered.

Françoise's eyes opened. She had a wild, crazy look on her face. She had not been asleep. "I want to go." She stood up from the bed. "It's not safe here."

"Françoise, please." Richard said. "This is a hospital."

"I'm taking my boy."

Françoise staggered toward the infant-nursery. Richard tried to hold her hands. She had become very strong. She screamed and fought. She said she was going to die.

\section{Françoise's eyes opened. She had a wild, crazy look on her face. She had not been asleep. "I want} to go." She stood up from the bed. "It's not safe here."

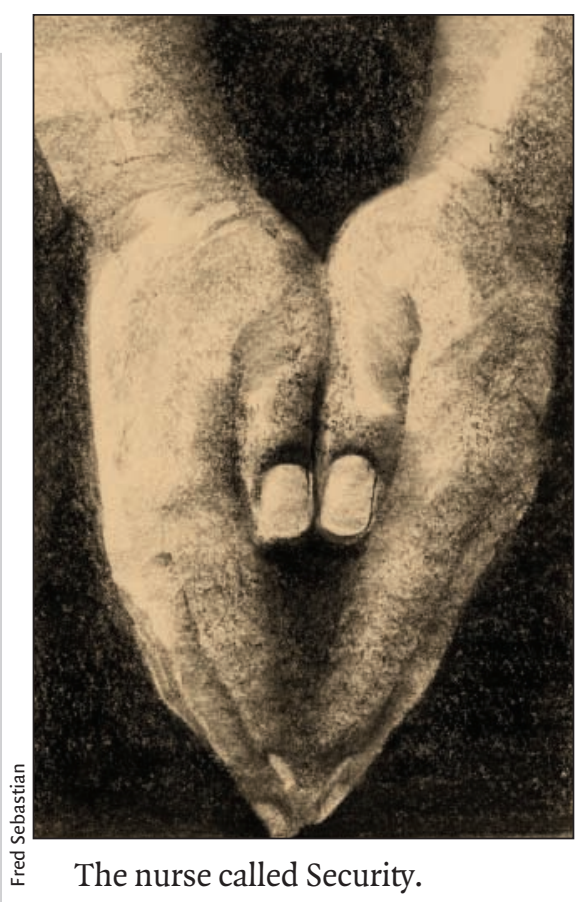

At ten a lanky doctor with ruddy cheeks and an English accent arrived with a clipboard and fountain pen. $\mathrm{He}$ paused to wait for the nurse's introduction.

"I won't talk if you leave me." Françoise clasped the nurse's hand. "Stay."

"I will translate," the nurse said.

The psychiatrist began. He asked Richard if he were abused, or if he had abused others. Richard pressed his huge hands together. Tears fell from his eyes. "I never hurt anyone," Richard said. "But I will kill whoever hurts Françoise."

The psychiatrist probed if Françoise were depressed or had thoughts of harming others. She stood up from bed and washed her hands. This time she poured a great quantity of antiseptic soap into her palms and lathered her forearms, until she was covered with soap past her elbows. Twice she did this, as if it were an ablution.

The psychiatrist asked her what she was thinking when she washed her hands. He asked about Françoise's parents. Gently, he asked when the abuse 
began. So, father had sex with her. But mother did nothing. Is that right?

Françoise looked at the nurse and nodded. Father blamed her for the pregnancies.

She had not uttered a word to anyone.

"This talking - will it make her better?" Richard held her small, roughened hands.

After the interview, the psychiatrist conferred with the nurse.

"She had no one before Richard. She's not suicidal - it's severe trauma with obsessions," the psychiatrist looked grim. "It's devastating to face — she needs help."

"I lived in her town," the nurse said. "I knew the family — but not this."

"I need someone to follow her," the psychiatrist stroked his brow. "There are legal issues, family issues. May I call you later?"

"Yes."

At eleven-thirty the nurse phoned to tell her family she would be late. Then she drove home.

When she entered, her husband frowned. He was sweeping the kitchen.

Two daughters morosely put away the washed breakfast dishes.

"My wife is late," the husband moaned. "She forgets she has a family."

The nurse absently took a glass and held it to the light.

It was clear and clean and sparkled in the sunlight.

She put it away.

She had no words left.

\section{Ronald Ruskin \\ Department of Psychiatry \\ Mount Sinai Hospital \\ Toronto, Ont.}

\section{Annotation}

\section{The surgeon and the nurse}

One of the most unflattering portrayals of a surgeon ever to appear in English literature is surely this introductory stanza from Alfred, Lord Tennyson's narrative poem, "In the Children's Hospital" (I880).

Our doctor had call'd in another, I never had seen him before, But he sent a chill to my heart when I saw him come in at the door, Fresh from the surgery-schools of France and of other lands Harsh red hair, big voice, big chest, big merciless hands! Wonderful cures he had done, $\mathrm{O}$, yes, but they said too of him He was happier using the knife than in trying to save the limb, And that I can well believe, for he look'd so coarse and so red, I could think he was one of those who would break their jests on the dead, And mangle the living dog that had loved him and fawn'd at his knee Drench'd with the hellish oorali — that ever such things should be! ${ }^{1}$

With the mention of oorali - i.e., curare, a South American arrow poison that induces paralysis but not a loss of consciousness - Tennyson likens this ham-handed fellow to a diabolical vivisectionist.

Fortunately for surgeons, the poem is not judged one of Tennyson's best: it is a decidedly mawkish rendition of a story the poet heard from Mary Gladstone, daughter of the English statesman. But it has a narrative complexity typical of the dramatic monologue form perfected by another Victorian, Robert Browning. The speaker is a nurse; she addresses herself to a sympathetic listener, an unnamed benefactor of the hospital. In 72 lines her tale manages to include a kindly generalist, the callous surgeon, a boy mangled in an industrial accident, a winsome orphan named Emmie, afflicted with an unspecified but riskily operable disease, and "wise little Annie," her spiritual confidante in the next bed.

The nurse, in contrast to the godless surgeon, seeks through prayer the fortitude to bear "the sights and the loathsome smells of disease." Not to mention the tragedies over which she powerlessly presides. Young Emmie, after overhearing her physician say that she will not survive surgery, implores God to take her directly to heaven, sparing her the ordeal. Sadly but mercifully, her prayer is answered. - Anne Marie Todkill, CMAJ

\section{REFERENCE}

I. Tennyson A. In the children's hospital, lines I-Io. In: Hill R W. Tennyson's poetry: authoritative texts, juvenilia and early responses criticism. New York: Norton; I97I. p. 447. 